\title{
Proximate and Mineral Compositions of Noodles Made from Triticum durum, Digitaria exilis, Vigna unguiculata Flour and Moringa oleifera Powder
}

\author{
Catherine A. Orisa ${ }^{1}$ and Ukpong S. Udofia(Ph.D) ${ }^{2}$ \\ 1. Department of Food Science \& Technology, Rivers State University, Nkpolu-Oroworukwo, Port Harcourt 500262, Nigeria \\ 2. Department of Home Economics, Nutrition \& Dietetics, University of Uyo, Uyo 520261, AkwaIbom State, Nigeria
}

\begin{abstract}
The objective of this study was to determine the proximate, mineral and sensory properties of noodles prepared from blends of Triticum durum (wheat), Digitaria exilis(acha), Vigna unguiculata (cowpea) flours and Moringa oleifera leaf powder (MLP). The flour samples were mixed in a four by four factorial, in complete randomized design (CRD) to formulate the composite blends at four different levels (25, 50, 75 and 100) which gave 16 samples. The flour samples were used to produce noodles and subjected to proximate, mineral and sensory analysis. Results of the proximate composition revealed that moisture content of the noodles ranged from $8.04-13.81 \%$, ash $1.84-3.67 \%$, fat $1.95-3.61 \%$, crude protein $10.07-14.44 \%$, carbohydrate $33.15-61.45 \%$, dietary fibre $16.65-36.22 \%$ and caloric value $214.53-288.28 \mathrm{~kJ} / 100 \mathrm{~g}$. There was a significant increase $(p<0.05)$ in the moisture, ash, fat, crude protein and dietary fibre of the noodles on the substitution with cowpea flour, acha flour and MLP. Results of mineral composition also showed that sodium content ranged from 1.58-11.76 mg/100 g, potassium 26.70-40.40 mg/100 g, calcium $18.03-59.02 \mathrm{mg} / 100 \mathrm{~g}$, iron 6.18-21.53 mg/100 g and phosphorus 0.51-1.54 mg/100 g. Noodle sample produced from 75\% wheat and $25 \%$ cowpea flours were significantly higher $(p<0.05)$ in mineral content (except for potassium). Sensory evaluation results showed that cowpea and acha flours can be substituted at $25 \%$ levels with $75 \%$, wheat flour and acha flour can as well be substituted at $50 \%$ with 50\% cowpea flour while MLP at $2 \%$ with $50 \%$ wheat flour, $23 \%$ acha flour and $25 \%$ cowpea flour without significantly ( $p<$ 0.05 ) affected the sensory attributes of the noodles. This result therefore indicates that the use of these locally grown crops has the potential to increase the nutritional intake of consumers of this product.
\end{abstract}

Key words: Proximate, mineral, acha, cowpea, Moringa oleifera.

\section{Introduction}

Noodles are widely consumed throughout the world since it is convenient, easy to cook and of low cost with a relatively long shelf life [16]. According to Ref. [14], noodles are known for low fat and sodium, and rich in complex carbohydrates. This has resulted in the research and development of noodles from locally grown crops with good nutrition, function and acceptability to consumers such as wheat/sweet potato/soybean/corn flours [35], wheat/cowpea/pomegranate peel power [40], wheat/stinging nettle flour blends [14],

Corresponding author: Catherine A. Orisa and Ukpong S. Udofia, Ph.D. wheat/mangsteen pericarp powder [30].

Acha (Digitaria exilis), also called fonio or hungry rice is an annual crop indigenous to West Africa which is classified as an underutilized crop [24]. In Nigeria, it is widely cultivated and consumed in the Northern Areas. It can be consumed whole, milled into flour or processed to gruel, porridges, alcoholic and non-alcoholic beverages [13]. They are a good source of magnesium, iron and copper but low in potassium, sodium lead and manganese than most cereals [24]. They also contain $7.9 \%$ protein, $1.8 \%$ fat, $71 \%$ carbohydrate and $6.8 \%$ fibre [33].

Cowpea (Vigna unguiculata) is a tropical legume crop which is grown particularly in the semi-arid West Africa Savannah [34]. The seeds of cowpea contain 
$20-25 \%$ protein, $1.5-4 \%$ crude fiber, $1-2 \%$ fat, $3-4 \%$ ash and 55-68\% carbohydrate in addition to vitamins and beneficial phytochemicals [21]. It can be cooked in the dried form, sprouted, consumed in the form of bean pudding "akara” (fried cowpea paste) or moi-moi (steamed cowpea paste).

Moringa oleifera is a plant which is native to India, Pakistan, Bangladesh and Afghanistan [20]. They are regarded as good sources of minerals, high ash, lipids, crude fibre and protein contents [4]. Broin [11] also reported that fresh leaves of Moringa oleifera contain at least twice more proteins than the protein of milk and of eggs. Different parts of Moringa oleifera have been used for soup making [10], weaning foods [9], amala [27] and cookies production [19]. The leaves can be consumed either in raw, cooked or dried forms and can also serve as a nutritional supplement in foods such as pap, cereals and drinks in order to improve their nutritive value [22].

Nutrition, health and convenience are major factors needed for development of a variety of products in today's world [40]. This has resulted to food industries in developing strategies for increasing profitability and improving the nutritional quality of products containing all essential nutrients required for human health [29]. Wheat and acha flours are high in carbohydrate but low in protein content therefore blending of these cereals with cowpea which is legume and Moringa oleifera for the production of noodles would help to improve the nutritional value of noodles and also alleviate the issue of protein-energy malnutrition. Wheat flour is the basic raw material for noodle production, however, in Nigeria, wheat production is limited and importation of wheat flour to meet local demand is necessary. Recently the use of composite flour in which flour from locally grown crops replaces a portion of wheat flour is common so as to meet the high demand for functional foods as well as decreasing the demand for imported wheat and encouraging the production and use of locally grown non-wheat agricultural products [42]. Therefore, the objectives of this study were to produce noodles from the substitution of wheat flour with acha, cowpea flour and Moringa oleifera leaf powder (MLP) and assess the proximate, mineral and sensory properties of noodles with a view of improving nutritional value, reducing cost and enhancing food security.

\section{Materials and Methods}

\subsection{Sample Collection}

Wheat (Triticum durum) flour (WF) was gotten from Dufil foods Choba in Obiakpor Local Government Area of Rivers State. Digitaria exilis and Vigna unguiculata were purchased from town market in Port Harcourt Local Government Area of Rivers State while Moringa oleifera (matured and newly developed leaves) was harvested from a Moringa oleifera farm in Sakpenwa, Tai Local Government Area of Rivers State. Identification of the plant materials was done by a plant taxonomist in the Department of Botany and Ecological Studies, University of Uyo to ascertain that the right materials were used for the research.

\subsection{Sample Preparation}

\subsubsection{Preparation of Acha (Digitaria exilis) flour} (AF)

Acha flour was prepared according to the method of Ref. [2]. Five kilograms (5 kg) of Digitaria exilis grains were manually cleaned and sorted by hand-picking of the chaff and foreign materials. Dust and sands were removed by washing severally with plastic bowls using clean tap water. The washed grains were sun dried for $6 \mathrm{~h}$ in a sunny day, after which the dried grains were finely milled into flour with a Kenwood Manual Milling Machine (Model AT941A), sieved through a size $14 \mathrm{~mm}$ mesh sieve to remove coarse and fibrous materials. The flour was stored in Ziplock bags at estimated room temperature for further use. 


\subsubsection{Preparation of Cowpea (Vigna unguiculata)} Flour (CF)

This was produced according to the method of Ref. [8]. Five kilograms (5 kg) of Vigna unguiculata was cleaned and sorted by hand, washed and manually dehulled. The dehulled seeds were oven dried at $60^{\circ} \mathrm{C}$ for $6 \mathrm{~h}$ and then milled into flour with a Kenwood Manual Milling Machine (Model AT941A). The flour was sieved using size $14 \mathrm{~mm}$ mesh sieve and stored in Ziplock bags at estimated room temperature for further use.

\subsubsection{Preparation of MLP}

MLP was prepared according to the method of Ref. [19]. Moringa oleifera was manually selected by hand to get healthy leaves while diseased and damaged leaves were discarded. Three kilograms $(3 \mathrm{~kg})$ of selected leaves were washed in running tap water for 10 minutes to remove dirt and dust. The washed leaves were soaked in $1 \%$ saline solution $(\mathrm{NaCl})$ for 5 minutes and rinsed twice with 1.5 litres of distilled water. The excess water on the leaves was removed by spreading the leaves in a colander for a brief period till the water present on the leaf surface was drained. The leaves were then dried thoroughly using a clean muslin cloth in a shaded area until it was well dried. The dried leaves were milled to powder using a
Kenwood Milling Machine (Model AT941A). The resulting powder was stored in air tight labelled plastic bottles at room temperature protected from light and humidity for further use.

\subsubsection{Formulation of Composite Blends}

Digitaria exilis flour, Vigna unguiculata flour, Triticum durum flour and MLP were mixed in four by four factorial, in complete randomized design (CRD) to formulate the composite blends at four different levels (25, 50, 75 and 100) that gave 16 treatments as shown in Table 1 below. MLP was used at lower levels because of the colouration that will be introduced to the product and the reductions added to the main flour in each sample.

\subsection{Production of Noodles}

Noodles were produced using the method described by Ref. [36]. Composite flours were mixed separately as shown in Fig. 1 with warm water $\left(40{ }^{\circ} \mathrm{C}\right)$ and $5 \%$ carboxymethylcellulose (CMC). The mixture was thoroughly kneaded to form dough. The dough was allowed to rest for 20 minutes, then kneaded again and rolled with a rolling pin to form sheets. The sheets were extruded using a cold extruder. The noodle strands were put in cleaned aluminium trays and oven dried at $70{ }^{\circ} \mathrm{C}$.

Table 1 Formulation of composite flour blends.

\begin{tabular}{lllll}
\hline Treatments & WF (\%) & AF (\%) & CF (\%) & MLP (\%) \\
\hline $100 \%$ WF & 100 & - & - & - \\
$75 \%$ WF, 25\% CF & 75 & - & 25 & - \\
$50 \%$ WF, 50\% CF & 50 & - & 50 & - \\
$36 \%$ WF, 25\% AF, 25\% WF, 14\% MLP & 36 & 25 & 25 & 14 \\
$100 \%$ CF & - & - & 100 & - \\
$25 \%$ AF, 75\% CF & - & 25 & 75 & - \\
$50 \%$ AF, 50\% CF & - & 50 & 25 & - \\
$50 \%$ WF, 23\% AF, 25\% CF, 2\% MLP & 50 & 23 & - & 20 \\
$100 \%$ AF & - & 100 & - & - \\
$80 \%$ AF, 20\% MLP & - & 80 & - & - \\
$50 \%$ WF, 50\% AF & 50 & 50 & - & 20 \\
$75 \%$ WF, 25\% WF & 75 & 25 & - & 14 \\
$80 \%$ WF, 20\% MLP & 80 & 36 & 25 & 2 \\
$50 \%$ WF, 36\% AF, 14\% MLP & 50 & 42 & 48 & \\
$25 \%$ WF, 42\% AF, 25\% CF, 8\% MLP & 25 & 25 & & \\
\hline
\end{tabular}




\subsection{Sensory Analysis}

Twenty grams (20 g) of each noodle were cooked using $1 / 4$ cup of boiling water for 3 minutes and stirred occasionally. Seasonings from the commercial indomie noodles wew added to taste and cooked until the water almost dried up. The cooked noodles were coded and served the panelists for sensory analysis. Sensory analysis was done on the noodles using a nine-point hedonic scale ranging from nine (9) liked extremely to one (1) disliked extremely as described by Ref. [25]. The noodle samples made from the different flours were presented using 100\% durum wheat flour as the control for sensory evaluation. Twenty (20) semi-trained panelists who were familiar with noodles and were neither sick nor allergic to it were involved in the assessment. The samples were rated for appearance, taste, flavour, and general acceptability.
The statistical analysis of data collected was used to select five (5) generally accepted samples (100\% Triticum durum; 75\% Triticum durum and 25\% Vigna unguiculata; 50\% Digitaria exilis and 50\% Vigna unguiculata; 50\% Triticum durum, 23\% Digitaria exilis, 25\% Vigna unguiculata and 2\% Moringa oleifera; and 75\% Triticum durum and 25\% Digitaria exilis) based on significantly highest means in the different parameters used.

\subsection{Proximate Analysis}

Moisture, ash, protein, fat and dietary fibre content were determined according to the method of Ref. [7] while carbohydrate was determined by difference.

\subsection{Energy Determination}

The energy content (E) of the noodles was calculated using Atwater factor as described by Ref. [32].

Mixing of ingredients (flours, warm water, CMC)

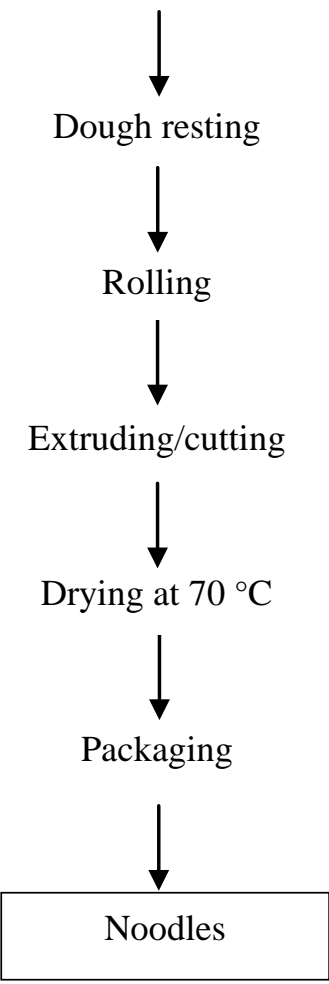

Fig. 1 Production of noodles.

Source: Ref. [36]. 


\subsection{Mineral Analysis}

Sodium, calcium, potassium and iron content were determined using buck scientific Z10 VGP atomic absorption spectrophotometer while molybdate method was used for the analysis of phosphorus as described by Ref. [6].

\subsection{Statistical Analysis}

All data obtained from the chemical, functional/pasting properties and sensory analysis were subjected to analysis of variance (ANOVA) using the Statistical Analysis System [38]. Means were compared using Least Significance Difference (LSD) with significant difference determined at 5\% probability level $(p<0.05)$. Determinations were carried out in triplicates.

\section{Results/Discussions}

\subsection{Proximate Composition of Noodles Produced from} Wheat Flour, Cowpea Flour, Acha Flour and MLP

Table 2 shows the proximate composition of noodles produced from wheat flour, cowpea flour, acha flour and MLP. Moisture content of the noodle samples ranged from $7.91 \%$ in sample D $(50 \%$ Triticum durum, 23\% Digitaria exiliis, 25\% Vignaunguiculata, $2 \%$ Moringa oleifera) to $13.81 \%$ in sample B (75\% Triticum durum, 25\% Vigna unguiculata). Moisture content of control noodle sample (100\% wheat flour) and sample D (50\% WF:23\% AF:25\% CF:2\% MLP) was not significantly different $(p>0.05)$ while other samples showed significant differences $(p<0.05)$ from each other. Moisture content of the noodles (except for sample with $75 \%$ WF and $25 \%$ CF) was below the $10-11 \%$ moisture level recommended for safe keeping of dried pasta and macaroni [31].

Moisture content of noodles from the present study was within the range of $8.03-10.10 \%$ for wheat/orange fleshed sweet potato [39], and higher than 11.53-12.40\% for wheat/orange fleshed sweet potato/African bean yam flour noodles [17]. The low moisture content of the noodles is preferable because it helps to extend its shelf life. Generally, the shelf life of noodles is dependent on its moisture content because of microbial activities in the product which result in spoilage [39].

Protein content of the noodles ranged from $10.07 \%$ in control sample to $14.44 \%$ in sample C (50\% AF:50\% $\mathrm{CF})$. Moisture content of sample $\mathrm{C}$ was significantly higher $(p<0.05)$ than other noodle samples while the control sample was not significantly different $(p>$ 0.05) from sample E (75\% WF:25\% AF). There was an increase in protein content of the noodles on substitution with cowpea flour, acha flour and MLP. Comparable results were reported from noodles produced from wheat/orange fleshed sweet potato/African bean yam flour noodles which ranged from 11.67-13.04\% [17]. Protein content of the noodles in the present study was higher than $5.88-7.79 \%$ for trifoliate yam-wheat noodles [5], 2.63-4.47\% for yellow noodles substituted with mangosteen pericarp

Table 2 Proximate composition of noodles produced from wheat flour, cowpea flour, acha flour and MLP.

\begin{tabular}{|c|c|c|c|c|c|c|c|}
\hline Treatments & $\begin{array}{l}\text { Moisture } \\
\text { content } \\
(\%) \\
\end{array}$ & $\begin{array}{l}\text { Ash } \\
(\%)\end{array}$ & $\begin{array}{l}\text { Fat } \\
(\%)\end{array}$ & $\begin{array}{l}\text { Crude protein } \\
\text { (\%) }\end{array}$ & $\begin{array}{l}\text { Available } \\
\text { carbohydrate } \\
(\%)\end{array}$ & $\begin{array}{l}\text { Dietary } \\
\text { fibre } \\
(\%)\end{array}$ & $\begin{array}{l}\text { Caloric value } \\
(\mathrm{kJ} / 100 \mathrm{~g})\end{array}$ \\
\hline $100 \% \mathrm{WF}$ & $8.04^{\mathrm{d}}$ & $1.84^{\mathrm{d}}$ & $1.95^{\mathrm{d}}$ & $10.07^{\mathrm{C}}$ & $61.45^{\mathrm{a}}$ & $16.65^{\mathrm{d}}$ & $288.28^{\mathrm{a}}$ \\
\hline $75 \%$ WF, 25\% CF & $13.81^{\mathrm{a}}$ & $3.11^{\mathrm{bc}}$ & $2.92^{\mathrm{b}}$ & $11.47^{\mathrm{b}}$ & $48.65^{\mathrm{C}}$ & $20.04^{\mathrm{cd}}$ & $254.60^{\mathrm{b}}$ \\
\hline $50 \%$ AF, 50\% CF & $8.91^{c}$ & $3.67^{\mathrm{a}}$ & $3.61^{\mathrm{a}}$ & $14.44^{\mathrm{a}}$ & $33.15^{\mathrm{e}}$ & $36.22^{\mathrm{a}}$ & $214.53^{d}$ \\
\hline $\begin{array}{l}50 \% \text { WF, } 23 \% \text { AF, } \\
25 \% \text { CF, } 2 \% \text { MLP }\end{array}$ & $7.90^{\mathrm{d}}$ & $3.29^{b}$ & $2.98^{\mathrm{b}}$ & $11.81^{\mathrm{b}}$ & $45.25^{\mathrm{d}}$ & $28.77^{\mathrm{b}}$ & $243.75^{c}$ \\
\hline $75 \% \mathrm{WF}, 25 \%$ AF & $10.51^{\mathrm{b}}$ & $3.10^{c}$ & $2.28^{\mathrm{C}}$ & $10.72^{\mathrm{c}}$ & $52.01^{\mathrm{b}}$ & $21.38^{\mathrm{c}}$ & $258.14^{\mathrm{b}}$ \\
\hline LSD (0.05) & 0.44 & 0.19 & 0.25 & 0.65 & 1.36 & 4.16 & 3.92 \\
\hline
\end{tabular}

Means with the same letters along the same column are not significantly different $(p>0.05)$. 
powder [30]. This result therefore indicates that noodles of improved protein could be produced from substitution of wheat flour with cowpea flour, acha flour and MLP.

Fat content of the noodles ranged from $1.95 \%$ in control wheat flour noodle to $3.61 \%$ in sample C $(50 \%$ AF:50\% CF). Fat content of sample C was significantly higher $(p<0.05)$ than all other samples while samples B (75\% WF: 25\% CF) showed no significant difference $(p>0.05)$ with sample D $(50 \%$ WF:23\% AF:25\% CF:2\% MLP) and sample E (75\% WF:25\% AF). There was an increase in the fat content of the noodles and this increase was more when the substitution of cowpea flour increased. This observation could be due to higher content of fat in cowpea and MLP as compared to wheat flour. These results are comparable to $1.39-3.00 \%$ for wheat/cassava noodles reported by Ref. [36]. Ref. [12] also reported an increase in fat content with addition of Bambara groundnut on wheat (1.69-6.28\%) for noodle production. Fat is essential component of tissues and a veritable source for fat soluble vitamins such as A, D, E and K [41].

Ash content of the noodle samples ranged from $1.84 \%$ in control wheat flour noodle to $3.67 \%$ in sample C (50\% AF:50\% CF). Ash content of sample $\mathrm{C}$ was significantly higher $(p<0.05)$ than all other samples while samples B (75\% WF:25\% CF), sample D (50\% WF:23\% AF:25\% CF:2\% MLP) and sample E (75\% WF:25\% AF) showed no significant difference $(p>0.05)$ from one another. An increase in ash content was observed for the noodle samples on substitution with cowpea flour, acha flour and MLP. Ash content of a food sample is an index of the mineral elements of such food. This indicates that the noodles formulated from composite flours would contribute more mineral elements to the product than $100 \%$ wheat flour noodle. This result is in correlation with that of Ref. [12] who reported an increase in ash content of wheat noodles on substitution with fermented Bambara groundnut flour (1.80-3.08\%).
The results of the present study are higher when compared with $1.35-2.11 \%$ for wheat/orange-fleshed sweet potato/African yam bean flour blend noodles as reported by Ref. [17].

Dietary fibre content of the noodles ranged from $16.65 \%$ in wheat flour noodle to $36.22 \%$ in sample C (50\% AF:50\% CF). Dietary fibre of control sample was not significantly different from sample B (75\% WF:25\% CF) while sample C was significantly higher $(p<0.05)$. An increase in the dietary fibre of the noodles was observed on the substitution with acha flour, cowpea flour and MLP. Dietary fibre content of the noodle samples is higher than $8.94-9.46 \%$ for noodles fortified with cowpea and pomegranate peel powder [40]. It is also far higher than $0.08-2.65 \%$ for wheat noodles supplemented with nettle leave flour [14]. Increased dietary fibre consumption could lead to significantly lower risks for obesity and some cancer [28].

Carbohydrate content of the noodles ranged from $61.45 \%$ in control noodle sample to $33.5 \%$ in sample C (50\% AF and 50\% CF). There was a significant difference $(p<0.05)$ in the carbohydrate content of the noodle samples. A decrease in the carbohydrate content of noodles on substitution with cowpea flour, acha flour and MLP was observed. The decrement is due to the fact that wheat is a high carbohydrate food and as the proportions of cowpea flour, acha flour and MLP supersede that of wheat, the carbohydrate content decreases. Similar results were reported by Ref. [12] for wheat/Bambara groundnut flour noodles (72.45-53.60\%). Carbohydrate content of the noodles from the present study was lower than $67.90-70.90 \%$ for wheat/orange-fleshed sweet potato/African yam bean flour noodles [17] and $75.10-77.32 \%$ for wheat/Bambara nut/cassava composite flour noodles [26]. The low carbohydrate content of the composite flour noodles has several benefits, as it aids digestion in the colon and reduces constipation often associated with products from refined wheat flour [18]. The decreased carbohydrate content of the noodles would 
also be useful to people who need low carbohydrate foods leading to enhanced health for overweight and obese persons.

Energy content of the noodles was in the range of $214.53 \mathrm{kcal} / 100 \mathrm{~g}$ in Sample C (50\% AF:50\% CF) to $288.28 \mathrm{kcal} / 100 \mathrm{~g}$ in control wheat flour noodles. A decreasing trend in the energy content of the noodles was observed on substitution with cowpea, acha flour and MLP. This could be due to lower amount of carbohydrate in cowpea flour, MLP and acha flour relative to wheat flour. This observation is in agreement with the reports by Ref. [14] who reported decreasing trend in energy content of noodles made from nettle leaves and wheat flour blends (351.45-367.38 kcal) as the substitution with nettle leaves increased.

\subsection{Mineral Composition of Noodles Produced from Wheat Flour, Cowpea Flour, Acha Flour and MLP}

Mineral content of noodles produced from composite flours of wheat, cowpea, acha and MLP is shown in Table 3. The results revealed that there were significant differences $(p<0.05)$ in the mineral elements among the produced noodles. This could be attributed to the differences in mineral composition of the different flours used in the composite flour formulation. In the present study, potassium and calcium were the most abundant elements in all the noodles produced. Potassium content ranged from $19.29 \mathrm{mg} / 100 \mathrm{~g}$ in control wheat four noodles to 40.40 $\mathrm{mg} / 100 \mathrm{~g}$ in noodles produced from the blend with equal proportions (50:50) of acha and cowpea flours. This value differed significantly $(p<0.05)$ to the values for the other noodles. Studies by Ref. [3] have shown that potassium intake is required in large amount in the body because it plays a role as an important electrolyte in the nervous system.

Calcium content also varied significantly $(p<0.05)$ among the noodles from varying flour blends and it ranged from $18.03 \mathrm{mg} / 100 \mathrm{~g}$ in $100 \%$ wheat flour noodles to $59.02 \mathrm{mg} / 100 \mathrm{~g}$ in noodles produced from $75 \%$ wheat flour and 25\% cowpea flour (Sample B). According to Ref. [1], calcium plays an important function as it aids blood clotting and muscle contraction.

Iron content of the noodles ranged from 6.18 $\mathrm{mg} / 100 \mathrm{~g}$ in noodles produced from $75 \%$ wheat flour and $25 \%$ acha flour (Sample F) to $21.53 \mathrm{mg} / 100 \mathrm{~g}$ in noodles produced from $75 \%$ wheat flour and 25\% cowpea flour (Sample B). There was a significant difference $(p<0.05)$ in the iron content of the noodles except for $100 \%$ wheat flour noodles and noodles produced from equal proportions of acha and cowpea flours. Iron is a critical micronutrient needed for the growth, development and health of infants [15]. It also plays an important role in the formation of hemoglobin "a component of blood cells that transports oxygen in the blood stream throughout the body" [23].

Sodium content varied from $1.58 \mathrm{mg} / 100 \mathrm{~g}$ in noodles produced from $50 \%$ wheat, $23 \%$ acha, $25 \%$ cowpea flours and 2\% MLP (Sample E) to 11.76 $\mathrm{mg} / 100 \mathrm{~g}$ in noodles produced from $75 \%$ wheat flour and 25\% cowpea flour (Sample B). There was a significant difference $(p<0.05)$ in the sodium content except for $100 \%$ wheat flour noodles which showed no significant difference $(p>0.05)$ with Samples E and

Table 3 Mineral composition (mg/100 g) of noodles produced from wheat flour, cowpea flour, acha flour and MLP.

\begin{tabular}{|c|c|c|c|c|c|}
\hline Treatments & $\mathrm{Na}$ & $\mathrm{K}$ & $\mathrm{Ca}$ & $\mathrm{Fe}$ & $\mathrm{P}$ \\
\hline $100 \% \mathrm{WF}$ & $2.65^{\mathrm{cd}}$ & $19.29^{\mathrm{e}}$ & $18.03^{\mathrm{e}}$ & $15.30^{\mathrm{b}}$ & $0.51^{\mathrm{e}}$ \\
\hline $75 \%$ WF, 25\% CF & $11.76^{\mathrm{a}}$ & $26.70^{\mathrm{d}}$ & $59.02^{\mathrm{a}}$ & $21.53^{\mathrm{a}}$ & $1.16^{\mathrm{c}}$ \\
\hline $50 \% \mathrm{AF}, 50 \% \mathrm{CF}$ & $7.06^{\mathrm{b}}$ & $40.40^{\mathrm{a}}$ & $21.13^{\mathrm{d}}$ & $15.10^{\mathrm{b}}$ & $0.68^{\mathrm{d}}$ \\
\hline $50 \%$ WF, $23 \%$ AF, 25\% CF, $2 \%$ MLP & $1.58^{\mathrm{d}}$ & $36.93^{\mathrm{b}}$ & $28.40^{\mathrm{b}}$ & $9.20^{c}$ & $1.54^{\mathrm{a}}$ \\
\hline 75\% WF, 25\% AF & $3.58^{\mathrm{c}}$ & $35.32^{c}$ & $28.73^{\mathrm{c}}$ & $6.18^{\mathrm{d}}$ & $1.26^{\mathrm{b}}$ \\
\hline LSD (0.05) & 1.67 & 1.02 & 0.12 & 0.99 & 0.05 \\
\hline
\end{tabular}

Means with the same letters along the same column are not significantly different $(p>0.05)$. 
F. Sodium regulates blood pressure and blood volume. The low sodium and high potassium contents of the noodles produced in the present study make them suitable for use by hypertensive individuals [24].

Phosphorus content of the noodles also varied significantly $(p<0.05)$ among the noodles with values ranging from $0.51 \mathrm{mg} / 100 \mathrm{~g}$ in noodles produced from $100 \%$ wheat flour to $1.54 \mathrm{mg} / 100 \mathrm{~g}$ in noodles from $50 \%$ wheat, 23\% acha, 25\% cowpea flours and 2\% MLP (Sample E). According to Ref. [37], phosphorus is a component of nucleic acids which plays an important function in the cellular metabolism of other nutrients such as carbohydrate, fat etc.

\subsection{Sensory Evaluation Result of Noodles Produced from Wheat Flour, Cowpea Flour, Acha Flour and $M L P$}

Table 4 below shows the mean sensory scores of noodles produced from wheat flour, cowpea flour, acha flour and MLP. Taste of the noodles ranged from 1.60 in noodles produced from $80 \%$ wheat and $20 \%$ MLP composite to 8.05 in $10 \%$ wheat flour noodles. Noodles produced from $100 \%$ wheat flour were highly preferred by the panelist with reference to taste, appearance, flavour and general acceptability and this could be as a result of it being produced from whole wheat flour which consumers are already accustomed to. However, sensory scores of taste, appearance, flavour and general acceptability of noodles produced from $100 \%$ wheat flour showed no significant difference $(p>0.05)$ with sample B (75\% WF:25\% cowpea flour blend noodles), sample G (50\% acha:50\% cowpea flour blend noodles), sample H (50\% WF:23\% AF:25\% CF:2\% MLP), and sample L (75\% WF:25\% acha flour blend noodles) while other samples were least preferred differing significantly $(p<0.05)$ to $100 \%$ wheat flour noodles. It was observed that noodle samples with high percentage of had low scores and this could be due to the green colour and bitter taste of the leaves which must have overshadowed the normal colour and taste of the noodles; however, noodles produced from at $2 \%$ substitution with a high percentage of wheat flour together with cowpea and acha flours were not significantly different $(p<0.05)$ from $100 \%$ wheat flour. This result therefore suggests that acceptable noodles can be produced from at $2 \%$ together with a higher percentage of wheat flour superseding that of cowpea and acha flours as well as

Table 4 Mean sensory scores of noodles produced from wheat flour, cowpea flour, acha flour and MLP.

\begin{tabular}{|c|c|c|c|c|}
\hline Treatments & Taste & Appearance & Flavour & General acceptability \\
\hline $100 \% \mathrm{WF}$ & $8.05^{\mathrm{a}}$ & $7.45^{\mathrm{a}}$ & $7.95^{\mathrm{a}}$ & $8.10^{\mathrm{a}}$ \\
\hline $75 \%$ WF, 25\% CF & $7.80^{\mathrm{a}}$ & $7.65^{\mathrm{a}}$ & $7.45^{\mathrm{a}}$ & $7.75^{\mathrm{a}}$ \\
\hline $50 \% \mathrm{WF}, 50 \% \mathrm{CF}$ & $3.20^{\mathrm{b}}$ & $3.50^{\mathrm{b}}$ & $2.40^{\mathrm{b}}$ & $3.20^{\mathrm{b}}$ \\
\hline $36 \%$ WF, 25\% AF, 25\% CF, 14\% MLP & $2.25^{\mathrm{b}}$ & $2.20^{\mathrm{bc}}$ & $2.4^{\mathrm{b}}$ & $2.70^{\mathrm{b}}$ \\
\hline $100 \% \mathrm{CF}$ & $1.80^{\mathrm{b}}$ & $2.95^{\mathrm{b}}$ & $1.15^{\mathrm{c}}$ & $2.70^{\mathrm{b}}$ \\
\hline $25 \%$ AF, $75 \%$ CF & $2.15^{\mathrm{b}}$ & $3.45^{\mathrm{b}}$ & $1.60^{\mathrm{C}}$ & $2.75^{\mathrm{b}}$ \\
\hline $50 \%$ AF, $50 \%$ CF & $7.30^{\mathrm{a}}$ & $7.15^{\mathrm{a}}$ & $6.80^{\mathrm{a}}$ & $7.50^{\mathrm{a}}$ \\
\hline $50 \% \mathrm{WF}, 23 \%$ AF, 25\% CF, $2 \%$ MLP & $7.15^{\mathrm{a}}$ & $7.80^{\mathrm{a}}$ & $7.40^{\mathrm{a}}$ & $7.35^{\mathrm{a}}$ \\
\hline $100 \% \mathrm{AF}$ & $3.15^{\mathrm{b}}$ & $3.05^{\mathrm{b}}$ & $2.40^{\mathrm{b}}$ & $2.45^{\mathrm{b}}$ \\
\hline $80 \%$ AF, 20\% MLP & $2.00^{\mathrm{C}}$ & $1.20^{\mathrm{C}}$ & $1.55^{\mathrm{c}}$ & $2.15^{\mathrm{bc}}$ \\
\hline $50 \% \mathrm{WF}, 50 \% \mathrm{AF}$ & $1.75^{\mathrm{c}}$ & $3.50^{\mathrm{b}}$ & $1.50^{\mathrm{C}}$ & $2.15^{\mathrm{bc}}$ \\
\hline $75 \% \mathrm{WF}, 25 \% \mathrm{AF}$ & $7.00^{\mathrm{a}}$ & $7.35^{\mathrm{a}}$ & $7.05^{\mathrm{a}}$ & $7.65^{\mathrm{a}}$ \\
\hline $80 \%$ WF, 20\% MLP & $1.60^{\mathrm{c}}$ & $1.30^{\mathrm{C}}$ & $1.45^{\mathrm{c}}$ & $1.40^{\mathrm{C}}$ \\
\hline $50 \% \mathrm{WF}, 36 \%$ AF, 14\% MLP & $1.90^{\mathrm{C}}$ & $1.70^{\mathrm{C}}$ & $1.30^{\mathrm{C}}$ & $1.15^{\mathrm{c}}$ \\
\hline $25 \%$ WF, 42\% AF, 25\% CF, 8\% MLP & $2.20^{\mathrm{bc}}$ & $2.75^{\mathrm{b}}$ & $1.40^{\mathrm{C}}$ & $1.95^{\mathrm{c}}$ \\
\hline $25 \% \mathrm{WF}, 25 \%$ AF, $48 \%$ CF, $2 \%$ MLP & $3.25^{\mathrm{b}}$ & $2.85^{\mathrm{b}}$ & $2.65^{\mathrm{b}}$ & $2.75^{\mathrm{b}}$ \\
\hline
\end{tabular}

Means with the same letters along the same column are not significantly different $(p>0.05)$. 
from equal blends of acha and cowpea flours without affecting the sensory attributes of the noodles.

\section{Conclusion}

The study has shown that it is possible to use composite of wheat, acha, cowpea and blends to produce acceptable noodles of high nutritional value. Noodles produced from the composite flour blends had higher nutritional content than control wheat flour noodles and these nutrients were higher when cowpea substitution into the blends increased. The study also showed that acceptable noodles can be produced from at $2 \%$ together with a higher percentage of wheat flour superseding that of cowpea and acha flours as well as from equal blends of acha and cowpea flours without affecting the sensory attributes of the noodles. The use of these locally grown crops will go a long way in reducing the Nation's reliance on wheat flour importation. Successful application of the composite flours in noodle production has the potential to increase the nutritional intake of the consumers of the product. This result will therefore have useful applications in the noodle industries since the product had comparable quality with $100 \%$ wheat flour noodles.

\section{References}

[1] Abulude, F. O., Lawal, L. O., Ehikhamen, G., Adesanya, W. O., and Ashafa, S. I. 2006. "Chemical Composition and Functional Properties of Some Prawns from the Coastal Area of Ondo State, Nigeria.” J. Environ. Agric. Food Chem. 5 (1): 1235-40.

[2] Adekunle, A. J., and Abiodun, A. V. 2018. "Proximate Composition, Physical and Sensory Quality of Acha-Moringa Seed Flour Blend Biscuits.” Asian Food Science Journal 5 (2): 1-7.

[3] Adrogue, M. D., and Madias, N. E. 2007. "Sodium and Potassium in the Pathogenesis of Hypertension." New Engl. J. Med. 356: 1966-78.

[4] Aja, P. M., Ibiam, U. A., Uraku, A. J., Orji, O. U., Offor, C. E., and Nwali, B. U. 2013. "Comparative Proximate and Mineral Composition of Moringa oleifera Leaf and Seed.” Global Advanced Research Journal of Agricultural Science 2 (5): 137-41.

[5] Akinoso, R., Olatoye, K. K., and Ogunyele, O. O. 2016.
"Potentials of Trifoliate Yam (Dioscorea dumetorum) in Noodles Production.” J Food Process Technol 7: 609. doi:10.4172/2157-7110.1000609.

[6] AOAC. 2006. Official Methods of Analysis. Association of Official Analytical Chemists. 18th edition. Washington, D.C., USA, 186-212.

[7] AOAC. 2010. Official Method of Analysis. Association of Official Agricultural Chemist. 18th Ed. Washington D.C., USA, pp. 102-5.

[8] Aremu, M. O., Olaofe, O., and Akintayo, T. E. 2006.“A Comparative Study on the Chemical and Amino Acid Composition of Some Nigerian Under-Utilized Legume Flours.” Pakistan Journal of Nutrition 5 (1): 34.

[9] Arise, A., Arise, R., Sanusi, M., Esan, O., and Oyeyinka, S. 2014. "Effect of Moringaoleifera Flower Fortification on Nutritional Quality and Sensory Properties of Weaning Food, Croat.” J Food Technology 6: 65-71.

[10] Babayeji, A., Ggbadebo, C., Obalowu, M., Otunola, G., Nmon, I., Kayode, R., Taye, A., and Ojo, F. 2014. "Comparison of Organoleptics Properties of Egusi and Eforiro Soup Blends Produced with Moringa and Spinach.” Food Sc. Qual. Manag. 28: 15-8.

[11] Broin, M. 2006. "The Nutritional Value of Moringaoleifera Lam. Leaves: What Can We Learn from Figures.” Afr. J. Biotechnol. 12 (37): 5559-66.

[12] Chude, C., Atowa, C. O., and Evangeline, O. 2018. "Quality Evaluation of Noodles Produced from Fermented Bambara Groundnut (Vigna subterranean (L.) Verdc.) Flour.” Food Science and Quality Management 73: 38-42.

[13] Coda, R., Di Cagno, R., Edema, M. O., Nionelli, L., and Gobbetti, M. 2010. "Exploitation of Acha (Digitaria exilis) and Iburu (Digitaria iburua) Flours: Chemical Characterisation and Their Use for Sourdough Fermentation.” Food Microbiol. 27 (8): 1043-50.

[14] Dagem, A., Gulelat, D., Kebode, A., Beruk, B. D., and Dereje, G. 2016. "Proximate, Mineral Composition and Sensory Acceptability of Home-Made Noodles from Stinging Nettle Leaves and Wheat Flour Blends.” International Journal of Food Science and Nutrition Engineering 6 (3): 55-61.

[15] Dewey, K. G. 2013. "The Challenge of Meeting Nutrient Needs of Infants and Young Children during the Period of Complementary Feeding: An Evolutionary Perspective.” Journal of Nutrition 143 (12): 2050-4.

[16] Ebtihal, Y. K., Hafez, D. A., and Sh. Ali, W. 2018. "Fortification of Instant Noodles Using Brassica oleracea to High Nutrition Value and Lowering Diabetics in Rats." Australian Journal of Basic and Applied Sciences 11 (5): 210-8.

[17] Effiong, B. N., Maduka, N., and Essien, A. G. 2018. "Evaluation of Wheat and Orange-Fleshed Sweet Potato 


\section{unguiculata Flour and Moringa oleifera Powder}

Composite Flour Fortified with African Yam Bean Flour for Instant Noodle Production.” Archives of Current Research International 13 (4): 1-15.

[18] Elleuch, M., Bedigian, D., Roiseux, O., Besbes, S., Blecker, C., and Atta, H. 2011. "Dietary Fibre and Fibre-Rich by Products of Food Processing: Characterization, Technological Functionality and Commercial Applications.” Review of Food Chemistry 124: 411-21.

[19] Emelike, N. J. T., Uwa, F. O., Ebere, C. O., and Kiin-Kabari, D. B. 2015. "Effect of Drying Methods on the Physico-Chemical and Sensory Properties of Cookies Fortified with Moringa (Moringa olelfera) Leaves.” Asian Journal of Agriculture and Food Sciences 3 (4): 361-7.

[20] Fahey, J. W. 2005. "Moringa oleifera: A Review of the Medical Evidence for Its Nutritional, Therapeutic, and Prophylactic Properties, Part 1.” Trees for Life Journal 1 (5): 1-17.

[21] Frank-Peterside, N., Dosumu, D. O., and Njoku, H. O. 2002. "Sensory Evaluation and Proximate Analysis of African Yam Beans (Sphenostylis sterocarpaltarms) Moimoi." Journal of Applied Sciences and Environmental Management 6 (2): 43-8.

[22] Gardener and Ellen. 2002. Moringa Tree Has Many Uses, from Food to Firewood. Yuma sun. Portal market, Moringa Tree Powder.

[23] Grosvernor, M. B., and Smolin, L. A.2002. Nutrition: From Science to Life. New York: Harcourt College Publishers, pp. 404-69.

[24] Inyang, U. E., Effiong, C. F., and Edima-Nyah, A. P. 2018. "Physical Properties, Nutritional Composition and Sensory Evaluation of Cookies Prepared from Rice, Unripe Banana and Sprouted Soybean Flour Blends.” International Journal of Food Science and Biotechnology 3 (2): 70-6.

[25] Iwe, M. O. 2010. Handbook of Sensory Methods and Analysis. Enugu: Rojoint Communication Services Ltd., pp. 75-8.

[26] James, S., Nwokocha, L., James, Y., Abdulsalam, R. A., Amuga, S. J., Ibrahim, I. B., and Yakubu, C. M. 2017. "Chemical Composition and Sensory Acceptability of Partially Gelatinised Pasta Produced from Blends of Wheat, Bambara Nut and Cassava Flours.” Journal of Tropical Agriculture, Food, Environment and Extension 16 (1): 26-30.

[27] Karim, O., Kayode, K., and Oyeyinka, A. 2015. "Physico Chemical Properties of Stiff Dough Amala Prepared from Plantain ( $M$. paradesca) Flour and $M$. oleifersleaf Powder.” Food Health Dis. 4: 48-58.

[28] Kranz, S., Brauchla, M., Slavin, J. L., and Miller, K. B. 2012. "What Do You Know about Dietary Fibre Intake in Children and Health? The Effect of Fibre Intake on
Constipation, Obesity and Diabetes in Children.” Advance Nutrition 3: 47-53.

[29] Kumar, S. B., and Prabhasankar, P. 2014. "Low Glycemic Index Ingredients and Modified Starches in Wheat Based Food Processing: A Review.” Trends Food Sci. Tech. 35 (1): 32-41.

[30] Mardiana, A. Z., Nurai, A. K., and Nur, S. S. 2015. "Effect on Nutritional and Antioxidant Properties of Yellow Noodles Substituted with Different Levels of Mangosteen (Garcinia mangostana) Pericarp Powder.” World Academy of Science, Engineering and Technology International Journal of Nutrition and Food Engineering 9 (5): 530-5.

[31] Mauer, L. J., and Bradley Jr, R. L. 2017. Moisture and Total Solids Analysis, Food Analysis, 5th ed. Springer International Publishing, pp. 257-86.

[32] Obiegbuna, J. E., and Baba, S. S. 2001. "Proximate Composition and Sensory Properties of Peanut and Melon Seed Butter Blends.” Journal of Sustainable. Agriculture and Environment 3: 326-30.

[33] Oburuoga, A. C., and Anyika, J. U. 2012. "Nutrient and Anti-nutrient Composition of Mungbean (Vigna radiate), Acha (Digitaria exilis) and Crayfish (Astacus fluviatilis) Flours.” Pakistan Journal of Nutrition 11 (9): 743-6.

[34] OECD. 2016. “Cowpea (Vigna unguiculata)”, in Safety Assessment of Transgenic Organisms in the Environment, Volume 6: OECD Consensus Documents, OECD Publishing, Paris.

[35] Olorunsogo, S. T., Adebayo, S. E., Orhevba, B. A., and Awoyinka, T. B. 2019. "Physicochemical Properties of Instant Noodles Produced from Blends of Sweet Potato, Soybean and Corn Flour.” Food Research 3 (5): 391-9.

[36] Omeire, G. C., Umeji, O. F., and Obasi, N. E. 2014. "Acceptability of Noodles Produced fromBlends of Wheat Acha and Soybean Composite Flours.” Nig. Food J. 32: 31-7.

[37] Sadawarte, S. K., Pawar, V. S., Sawate, A. R., Thorat, P. P., Shere, P. D., and Surendar, J. 2018. "Effect of Germination on Vitamin and Mineral Content of Horse Gram and Green Gram Malt.” International Journal of Chemical Studies 6 (3): 1761-4.

[38] SAS Institute. 2011. SAS Systems for Information Delivery for Windows. Version 9.2. Cary, NC: SAS Institute.

[39] Sunmonu, B. A., Rafiu, A., Tobiloba, O. M., Kayode, A. T., and Femi, O. G. 2018. "Quality Assessment of Noodles Produced from Wheat (Triticumaestivum), Orange Fleshed Sweet Potato (Ipomea batatas) and Sesame (Sesamumindicum) Blends." Journal of Environmental Science, Toxicology and Food Technology 12 (1): 24-9.

[40] Thorat, A. V., Kardile, N. B., and Wagh, R. P. 2018. "Physio-Chemical and Sensory Analysis of Noodles 
Fortified with Cowpea and Pomegranate Peel Powder.” International Journal of Chemical Studies 6 (4): 3051-4.

[41] Wardlaw, G. M. 2004. Perspectives in Nutrition, 6th ed. New York, U.S.A.: McGram Hill Companies.
[42] Yetunde, E. A., and Chiemela, E. C. 2015. "Proximate Composition, Physical and Sensory Properties of Cake Prepared from Wheat and Cocoyam Flour Blends.” Journal of Food Research 4 (5): 181-8. 